\title{
S. TYPHI-MURIUM MENINGITIS IN A PREMATURE INFANT DURING THE NEONATAL PERIOD
}

\author{
BY \\ V. W. PUGH and S. VAKIL \\ From Mile End Hospital, London
}

(RECEIVED FOR PUBLICATION MARCH 15, 1952)

In 1908 the first case of Salmonella meningitis was reported by Ghon, and since then 150 cases have been described (Metcalfe and Wiswell, 1950), of which 15 were due to $S$. typhi-murium; only two of these infants were definitely recorded as being under 1 month old at the time of infection. Debré and Mozziconacci (1949) record two cases of Salmonella meningitis one of which was due to $S$. typhi-murium and had occurred in the neonatal period. None has been described as occurring in the premature baby in the first month of life. We feel, therefore, that the case reported here is of interest.

\section{Case Report}

P., a boy, was delivered by forceps on September 20, 1951 , after a gestation period of approximately 37 weeks. The mother had suffered from pre-eclamptic toxaemia. There was no history of contact with infection.

The infant weighed $5 \mathrm{lb} .3 \mathrm{oz}$. $(2 \cdot 37 \mathrm{~kg}$.) at birth and had a skull circumference (occipito-frontal) of $12 \frac{1}{2}$ in. $(31 \cdot 25 \mathrm{~cm}$.). The baby breathed and cried well immediately after birth. There was a caput succedaneum over the right side of the skull, and there were two supernumerary auricles in front of the left external auditory meatus. The general condition of the baby was good, and no other abnormal physical signs were found.

Feeding was started when the baby was 2 days old, and he sucked well at the breast. On the third day, however, he was apathetic, his muscle tone poor, and he sucked weakly ; these symptoms increased and tube feeding became necessary on the fifth day. Jaundice was present on the sixth day and became more intense in the next 24 hours.

The weight gradually fell from $5 \mathrm{lb} .3 \mathrm{oz} .(2 \cdot 37 \mathrm{~kg}$.) at birth to $4 \mathrm{lb} .7 \frac{1}{2} \mathrm{oz}$. $(2 \cdot 04 \mathrm{~kg}$.) on the fourth day, and to $4 \mathrm{lb}$. $5 \frac{1}{2} \mathrm{oz}$. $(1.98 \mathrm{~kg}$.) on the ninth day. During the first nine days the temperature varied between $97^{\circ} \mathrm{F}$. and $98^{\circ} \mathrm{F}$. $\left(36 \cdot 1^{\circ} \mathrm{C}\right.$. and $36 \cdot 7^{\circ} \mathrm{C}$.). There had been no vomiting and the motions were normal in consistency and colour, the number varying from three to five per day. The fontanelle was of normal tension, and no abnormal physical signs were elicited. No twitching had been observed.

On the ninth day there was a rise of temperature to $99 \cdot 5^{\circ} \mathrm{F}$. $\left(36 \cdot 4^{\circ} \mathrm{C}\right.$. $)$ at $10 \mathrm{a} . \mathrm{m}$. and by $2 \mathrm{p} . \mathrm{m}$. the temperature was $104^{\circ} \mathrm{F}$. $\left(40^{\circ} \mathrm{C}\right.$.). The baby had an attack of cyanosis followed by a generalized convulsion, during which he vomited green fluid and passed a loose stool. During this attack the fontanelle was not tense and no other abnormal physical signs were found. He died at about 3.30 p.m.

Post-MORTEM FInDINGS. The body was that of a small pale infant weighing $4 \mathrm{lb} .5 \mathrm{oz}$. $(1.97 \mathrm{~kg}$.), with numerous red spots and blotches on the skin over the chest wall and arms. There were supernumerary auricles in front of the left external auditory meatus. There was no jaundice. The skull plates were congested, especially in the occipital region. The anterior fontanelle was normal. There was extensive purulent exudate throughout the meninges. Pale, greenish-yellow pus was accumulated around the pons, medulla, over the temporal lobes and up over the lateral surfaces of the parietal and frontal lobes on both sides, but maximal on the left side. From each of these accumulations there were extensions which followed the sulci and spread almost up to the longitudinal fissure. The meningeal vessels were grossly congested. No intracranial haemorrhage was seen, no internal hydrocephalus was found, and the middle ears were clean.

The pericardium was tense with clear, straw-coloured fluid: the heart was normal. The lungs were healthy and no lesions were seen in the intestines, which contained orange-yellow material. Other viscera were healthy.

BACTERIOLOGY. On opening the skull, swabs were carefully taken from the left cerebral hemisphere and from between the pons and the temporal lobe on the right side. Both swabs showed pus cells and Gram-negative bacilli on direct films. Cultures produced a pure growth of Gram-negative bacilli which had the characteristics of the Salmonella group. The antigenic structure of the organism was determined and was shown to be $S$. typhi-murium $(0=\mathrm{IV}, \mathrm{V}, \mathrm{XII}, \mathrm{H}=\mathrm{i}-1,2,3)$.

A search was made for the source of the infection. A girl, C, who was in the premature nursery with our patient during the first $\mathbf{1 2}$ hours of his life, had developed diarrhoea complicating pneumonia, and was isolated. The diarrhoea was shown to be due to $S$. typhi-murium. The rectal swab from this child's mother was initially negative for $S$. typhi-murium but later became positive. This mother later gave a history of having suffered from diarrhoea before delivery.

Unfortunately Mrs. P., the mother of our patient, had left hospital before the diagnosis of $S$. typhi-murium meningitis was made at necropsy, and no swab was taken. 
Rectal swabs were taken from all other mothers, babies and staff in the unit at the time the diagnosis was established and were found to be negative for S. typhi-murium.

The three organisms isolated were examined for their Vi-phage type at the Central Enteric Reference Laboratory and were found to belong to Vi-phage type Group 2, according to the provisional typing scheme of Felix and Callow which has not yet been published (Felix and Callow, 1943 ; Felix, 1951).

\section{Discussion}

The early clinical diagnosis of meningitis in the neonatal period is difficult, and is more so in a premature infant. The need for the early and accurate diagnosis has increased with the advent of the newer antibiotics which now offer successful treatment in those cases due to Gram-negative organisms.

Randall (1948), in his description of six fatal cases of neonatal meningitis due to Bact. coli, notes that there are few symptoms referable to the local condition. Kagan, Hess, Mirman and Lundeen (1949), in a paper on meningitis in the premature infant, review 45 cases in the literature and add 12 of their own. They list fever, cyanosis and vomiting as being the commonest signs in their own cases, and point out that nuchal rigidity and bulging of the fontanelle are often absent or late in onset.

Craig (1936) mentions that prematurity and infection in any part of the body are important predisposing factors. He lays stress upon the presence of intracranial irritation as manifested by nystagmus, restlessness and sponginess of the fontanelle. Many of his cases showed progressive wasting and sluggishness. Although fever was present in most cases, it was absent throughout the course of the illness in three.

In our case the clinical picture of apathy, weak sucking and loss of weight beginning on the third day of life was suggestive of intracranial birth injury. The prematurity and the history of forceps delivery supported this view, as did the absence of clinical evidence of infection.

However, this case confirmed the point that meningitis should always be excluded even though the classical signs are absent. The decision to perform a lumbar puncture in such cases must remain a difficult one, because of the comparative rarity of neonatal meningitis.

Debré and Mozziconacci (1949), in their paper on septicaemia and meningitis due to intestinal organisms in infants, found that the infection was most often localized in the meninges. They state that it is necessary to perform lumbar puncture in all cases, although they found that in three out of 25 cases with meningitis the cerebrospinal fluid was normal in all respects, despite the fact that suppurative meningitis was found at necropsy.
The causal organism of the meningitis is of interest, in that ours appears to be the third fully recorded case occurring in the neonatal period, and the first to be noted in a premature infant.

Henderson (1948) reports the case of a full-term infant weighing $6 \mathrm{lb}$. $5 \mathrm{oz}$. $(2,863 \mathrm{~g}$.) at birth, the clinical features being jaundice, vomiting and poor feeding on the second day, followed by the passing of green diarrhoeal stools and signs suggestive of bronchopneumonia. Later opisthotonos occurred, accompanied by a steep rise of temperature and followed by death at the tenth day.

In the case reported by Metcalfe and Wiswell (1950) the birth weight was $7 \mathrm{lb} .2 \frac{1}{2} \mathrm{oz}$., and irritability and bulging of the fontanelle were manifest on the sixteenth day of life. The localizing signs had been preceded by green diarrhoea for five days. This infant was successfully treated with streptomycin and sulphadiazine. In both these patients diarrhoea had been a prominent feature, and in the second case $S$. typhi-murium was isolated from the stools. Henderson also mentions that diarrhoea in Salmonella meningitis is commoner in the newborn period than in older infants. Guthrie and Montgomery (1939) quote Havens (1935) who stated that $B$. aertycke ( $S$. typhi-murium) is an organism which tends to remain localized in the intestine, although Smith (1934) has occasionally found it in cases of septicaemia, and there seems no reason why it should not invade the blood stream in young infants.

In our patient the absence of diarrhoea during life and the normal appearance of the intestine at necropsy are of interest since the route of infection cannot clearly be defined and remains obscure.

\section{Summary}

A fatal case of S. typhi-murium meningitis occurring in a premature infant during the first $\mathbf{1 0}$ days of life is reported. The literature is briefly reviewed.

We wish to thank Dr. K. H. Tallerman for permission to publish this case and for his advice in the preparation of the paper. Our thanks are due to Dr. Joan Taylor and to Dr. A. Felix for the serological identification and the phage-typing of the organisms isolated and for their permission to quote their results.

\section{RFFERENCES}

Craig, W. S. (1936). Archives of Diseases in Childhood, 11, 171.

Debré, R. and Mozziconacci, P. (1949). Brit. med. J., 2, 451.

Felix, A. (1951). Brit. med. Bull., 7, 153

and Callow, B. R. (1943). Brit. med. J., 2, 127.

Ghon, A. (1908). Bericht über den $\mathbf{X} I V$ internationalen Kongress für Hygiene und Demographie, Berlin, 1907, vol. 4, p. 21.

Guthrie, K. J. and Montgomery, G. L. (1939). J. Path. Bact., 49, 393.

Havens, L. C. (1935). The Bacteriology of Typhoid, Salmonella, and Dysentery Infections and Carrier States. New York.

Henderson, L. L. (1948). Amer. J. Dis. Child., 75, 351.

Kagan, B. M., Hess, J. H., Mirman, B. and Lundeen, E. (1949) Pediatrics, 4, 479 .

Metcalfe, D. C. and Wiswell, G. B. (1950). Canad. med. Ass. J., 62, 500.

Randall, K. J. (1948). J. clin. Path., 1, 150.

Smith, J. (1934). J. Hyg., Camb., 34, 351. 